\title{
Improving Teaching and Learning in Students with Deficient Language Mastery
}

\author{
Matthieu W. Yangambi \\ Department of Pedagogy, National Teaching University, Kinshasa, Democratic Republic of the Congo \\ Email: matthieuwy12@gmail.com
}

How to cite this paper: Yangambi, M. W. (2022). Improving Teaching and Learning in Students with Deficient Language Mastery. Creative Education, 13, 366-392. https://doi.org/10.4236/ce.2022.132022

Received: January 6, 2022

Accepted: February 11, 2022

Published: February 14, 2022

Copyright $\odot 2022$ by author(s) and Scientific Research Publishing Inc. This work is licensed under the Creative Commons Attribution International License (CC BY 4.0).

http://creativecommons.org/licenses/by/4.0/ (c) (i) Open Access

\begin{abstract}
Language mastery seems no longer be a necessity for communication. In media platforms, speaking and writing do not follow the rules of language for an effective communication. Language mastery becomes a very important concern for educators. The purpose of this study was to find out how to make teaching language mastery as effective as necessary, to determine whether students' lack of language mastery is imputable to ineffective teaching in classrooms and what teaching strategies could help educators to provide students with the language mastery they need. Three areas were explored: the teaching of the language, the implication of the language teaching in students learning, and the strategies needed to reach students language mastery. This study was conducted in three large high schools in the City of Kinshasa, the capital of the Democratic Republic of the Congo. The sample $(\mathrm{N}=167)$ was composed of 123 students and 44 volunteer teachers and was based on the non-probability sampling technique known as convenience sampling from students and teachers. The questionnaire was designed based on the literature related to effective language mastery using five-point numerical Likert-type scale. Several findings were of importance. First, students found that the approaches to teaching grammar/grammatical analysis led to consistent mastery of the language and this strategy was very important while teachers found it less important. Second, students found that the approaches to teaching grammar and grammatical analyses allow them to master the language rapidly while teachers found it not so important. The results of this study may inform educators and policy makers about strategies to implement in classrooms while teaching language mastery. Recommendations for practice are included.
\end{abstract}

\section{Keywords}

Literacy, Language Mastery, Teaching and Learning, Grammar 


\section{Introduction}

Language mastery is a necessary requirement for future success in education. Effective communication in school or in academic environment is, in somewhat, a layer of knowledge understanding and accumulation. Anyone unable to clearly communicate his or her thoughts would not easily become successful in life. In education, language mastery is indispensable for effective learning and exchanges as well as in discussing ideas. It also facilitates understanding of course content materials.

\subsection{Problem Statement}

Many students or anyone learning English or any other language as a second language have trouble communicating in a masterful way in the second language. Some just please themselves in communicating in social English or other language socially. Academic communication in English or in other second languages seems to be a hurdle, because it necessitates the mastery of academic English that is the mastery of the English as a second language or simply the mastery of any second language. Academic English facilitates the deep understanding of content materials and could make people successful in education or in life.

Students' deficient language mastery may be due to ineffective teaching of language throughout their educational cursus or to their status as second language learners. People with weak communication skills-oral or writing-would have difficult time to convince many audiences. What can we do to make teaching language as effective as necessary? Lack of language mastery, is it imputable to ineffective language teaching in classroom? Can students be the ones to inform educators about effective language teaching practices they prefer? In this work, we will set together ways to bring solutions to these necessary preoccupations about effective language teaching and effective students language mastery.

\subsection{Research Questions}

The following research questions were addressed in this study:

1) What can we do to make teaching language mastery as effective as necessary?

2) How can we determine whether students lacking language mastery is imputable to ineffective language teaching in classroom?

3) What teaching strategies can help educators to provide students with language mastery?

\subsection{Significance of the Study}

Lacking the mastery of a language cannot be ignored by conscientious and responsible educators. Language mastery should be an obligation for anyone who endeavors to succeed in life. Therefore, mastering a language, be it first or second, should be necessary for every productive individual in society. 


\subsection{Limitations}

There were some limitations to the current research study, with most of them concerning internal validity. The researcher encompassed only three high schools and it could only be assumed that teachers and students understood all questions very well. There was sparse research that addressed the topic.

A five-point numerical Likert-type scale rating provided data that were considered valuable, but responses in the middle of the range were difficult to interpret.

\subsection{Delimitations}

Although the study addressed teachers and students' perceptions of teaching language strategies, it did not examine teachers training and the linguistic and psychological theories of teaching languages. This study was based on language instruction leading to mastery. The researcher believed that students were the population who produced the results. Their opinions on teaching strategies could enlighten the research and help teachers to become more effective educators.

\section{Review of the Literature}

\subsection{Pillars of Effective Language Teaching}

According to the 5 pillars of effective language teaching established under the guise of the Council of Europe, the Council developed the Common European Framework of Reference (CEFR) in 2017, stating that language teaching strategies are the core of language mastery. The five pillars of effective language teaching recalled in the following lines are to be considered and applied if teachers are to reinforce English language or any language mastery to students (Language Center, 2017).

The Council of Europe developed the Common European Framework of Reference (CEFR) for language proficiency levels. The CEFR suggests five pillars of effective language teaching. The framework provides clarity on the interpretation of language proficiency levels across Europe, and outside Europe as well. The framework enables language learners to determine their existing and desired level by answering several questions about language use in specific situations. It also enables teachers to use clear, uniform standards in their courses and tests. The CEFR regularly organizes refresher training sessions for teachers to ensure that everyone uses the same standards and assessment criteria. Standards and tailored language tests are always related to the framework.

The CEFR encourages language learners to find their own most effective learning style. It asks them to regularly reflect on their learning process and ask themselves how they can most effectively learn and what motivates them most. Reflecting on their own learning will result in better awareness of their learning process. This method increases the chances of effective language acquisition continuing after the course.

The CEFR offer language learners a rich learning environment. The teacher guides the way and structures the learning process, and the student practices, 
learns and reflects. The course material consists not only of textbooks, but also offer students a wealth of online exercises, texts, videos, tips and tricks to help them improve the aspects that they find most important. Web 2.0 technology and media such as Skype, Facebook, Twitter, video conferencing, various apps, YouTube and MOOCs greatly enrich language teaching. The CEFR did not discuss differentiation strategies instead they discuss teaching strategies to help all students learn. They also discussed students learning according to their own ability.

\subsection{Essential Strategies for Teaching English Learners or Any Other Language Learners}

Kaplan (2019) interviewed senior educators with decades of experiences teaching second language learners. From these interviews, the following are some English language or other languages strategies to consider attaining students' language mastery:

\subsubsection{Cultivate Relationships and Be Culturally Responsive.}

Any successful language classroom, be it native or not native, is one in which students feel known, appreciated, and comfortable taking emotional and intellectual risks. This strategic approach requires intentional planning and consistent messaging. Emily Francis, an ESL teacher in Concord, North Carolina in 2019, stated that teachers must want their students to embrace their culture and their language as a foundation of who they are and to consider their acquisition of a new culture and language not as subtractive, but as additive.

According to Emily Francis, to help support students who may never have attended school before or may be coping with migration-based trauma, it should be emphasized that teacher's small actions can make big difference. The first action that teachers need to think about is their students feeling in their classroom. Are they sitting next to classmates they can ask questions in their home language? Do they feel comfortable tapping the teacher's shoulder if they must go to the bathroom? These are strategies for multicultural classrooms in which students are learning second languages.

Creating a supportive environment is also about cultivating an appreciation of diversity. It's critical that both the language curriculum and the classroom environment honor and reflect the lives of students. Classroom library should be reflective of students' diverse backgrounds and identities.

\subsubsection{Teach Language Skills across the Curriculum}

English or any other language learners should not be learning the fundamentals of the language in isolation. They should be applying their developing language skills to reach academic content in all subjects.

In mainstream classrooms, content material teachers should understand their role as language content teachers. Valentina Gonzalez, a district leader in Katy, Texas in 2019 suggested that all teachers should be aware of the specialized 
idiom they use in classrooms; emphasizing that if they teach math, then they teach the language of mathematics. If they teach science, then they teach the language of science. Math teachers, in other words, should take the time to teach the unfamiliar vocabulary of mathematics such as adding, subtracting, calculating, solving, concurrently with the teaching of math skills.

\subsubsection{Emphasize Productive Language}

Educators agreed that productive language skills-hard-to-master dimensions of language fluency like speaking and writing-should be front and center from day one, even if students feel hesitant about them.

Beginning language learner students often develop receptive language skills like listening and reading first. Educators who are unaware of the typical path to fluency may believe that students who can follow verbal or written directions will be able to produce oral or written language. Unfortunately, that's usually not the case. To support reluctant speakers, teachers should use sentence frames. For example, when a science teacher wants English Language Learner (ELL) students to produce a hypothesis, he/she might offer the sentence that would provide clues that empower ELLs to sound and think like scientists.

\subsubsection{Speak Slowly and Increase Your Wait Time}

Speaking slowly to learners of a second language give them opportunities or time to translate, to process their thinking, to translate back into English, and to develop the courage to answer. If teachers of second language students ask for quick answers, the manner would frustrate students who will stop thinking about the answers-or trying to answer at all.

\subsubsection{Differentiate and Use Multiple Modalities}

Second language learners learn better when they engage with material in multiple ways: Lessons that involve writing, speaking, drawing, and listening. For example, give students four opportunities to deepen their understanding of the work. For ELLs as for any student learning another language, those additional engagements also provide a little breathing room so they can work through the language barrier.

\subsubsection{Incorporate Students' Native Languages and Don't Be Afraid of Technology}

Educators should use a strategy called "preview, view, review," which leverages a student's native language skills as a foundation for learning the new language. They should introduce a topic and encourage students to preview it in materials in their home language. They should then teach the topic in the language, and then have students review the information in their home language.

Teachers should also embrace technologies that students find helpful like Google Translate. The app can be a useful way for students to translate words quickly taking caution that it becomes a dependency if it is used as more than a handy dictionary. 


\subsection{Lack of Language Proficiency}

According to Chong (2016), it has been shown that younger Malaysians today lack proficiency and competency in the English Language. To improve the English of present generation of students and young workforce, English teachers need to increase their opportunities of seeing, hearing and speaking the language. It is simply a basic and fundamental approach. Until now, it can be said that much has been done. However, much more needs to be done.

Social media, television shows and documentaries presented in first language to second language learners with English subtitles can considerably facilitate the mastery of the second language. The proposal here is to provide another convenient and ready avenue for those who want to learn English or other languages efficiently.

Displaying notices and signboards in public places in several languages specifically in first and second language would significantly improve people communication. An added advantage of this approach is that it will help and benefit many international tourists and visitors.

Public announcements at airports are made in multiple languages including English. Educators should strenuously and systematically request to extend such services and practices to other transport hubs like bus and railway terminals and ports; more so for those places where foreign travelers transit. Local travelers who are keen to learning English will have yet another avenue to read, to hear and to listen to the second language they are learning.

Marketing commercial products should also be labelled in both first and second languages. This strategy could also widen the second language learning exposure in many places and environment.

Concerted and intentional efforts must be made towards improving the second language deficiency, specifically the English language in second language learners. School systems are doing what they can to improve the second language learning. However, schools' efforts must be complemented and supplemented by out-of-school or external actions and activities.

\subsection{Improving Systems for Reading Instruction}

According to USAID organization, through research published on May 27, 2020, effective reading practice is one of the necessary elements of language mastery, the bedrock of literacy and the foundational skill necessary for all academic progress. Effective reading program should begin since elementary schools to ensure a pipeline of students who remain in school, achieve educational success, and contribute to economic growth. Because reading is a skill that must be carefully and explicitly taught, designing such programs is complex. Language of instruction policies and practices are critical to learning and improving children's reading outcomes (USAID, May 27, 2020).

Developing strong reading skills is essential to children's academic success 
and later life outcomes. Learning to read in a language that they use and understand, whether it's spoken or sign language, is one of the most critical factors in determining whether children develop the strong literacy skills that are foundational for all later learning. Even the most carefully designed reading lessons won't help children learn to read if they can't understand the language their teacher uses in the classroom.

\subsection{Teaching Grammar in Schools}

According to Julio Foppoli (Foppoli, 2021), teaching grammar in schools will help learners to understand the nature of the language. Grammar skills will enable learners to be aware of parts of the language such as verbs, nouns, adverbs, articles, usage of punctuations... Teaching grammar will help learners to understand and to use the grammatical concepts better.

Grammar is the backbone of a language and without it any single language construction may be unsound and incomprehensible. In a nutshell, grammar provides students with the structure they need to organize and to put messages and ideas across. It is the railway through which messages will be transported. No one won't be able to convey ideas to their full extension without a strong command of the underlying grammar patterns and structures of the language.

\subsection{The Necessity of Grammar Teaching}

According to Zhang (2009), grammar teaching is necessary in language teaching. The history of language teaching is essentially the history of the claims and counterclaims for and against the teaching of grammar. It is a subject that everyone involved in language teaching and learning has an opinion. And these opinions are often strongly and uncompromisingly stated.

As Penny Ur, in Zhang (2009), a teacher trainer and author of Grammar Practice Activities stated, there is no doubt that knowledge implicit or explicit of grammatical rules is essential for the mastery of a language. Michael Lewis, in Zhang (2009), a popular writer on teaching methods also stated that grammar is not the basis of language acquisition and, the balance of linguistic research clearly invalidates any view to the contrary.

Making up his mind, Zhang (2009) affirmed that grammar teaching is essential in language teaching field. English language learners who have been lacking in grammar rules instruction can neither use English language accurately to make a complete sentence, nor speak English language fluently on accuracy.

Because language knowledge of grammar and vocabulary is the base of English language and any other language, it is understandable that putting grammar in the forefront in second language teaching is essential. Grammatical competence is one of the communicative competences. Communicative competence involves knowing how to use the grammar and vocabulary of the language to achieve communicative goals and knowing how to do this in a socially appropriate way. Therefore, grammar teaching is necessary to achieve the goals (Zhang, 2009). 
According to the dictionary definition, there are at least two senses of the word grammar. First, it is a study or science of or rules for the combination of words into sentences (syntax) and the forms of words (morphology).

Second, it is a book containing the rules of grammar of a language. Language teaching is generally concerned with the first, an uncountable meaning of grammar. The grammar is a system of rules (or patterns) which describe the formation of a language's sentences (Zhang, 2009).

Some learners acquire second language grammar naturally without instruction. There are immigrants to the United States who acquire proficiency in English on their own. This is especially true for young immigrants but not true for all learners.

Though highly motivated learners with a particular aptitude for languages may achieve a degree of proficiency without any formal instruction, their English output is far from accurate. Studying grammar can consolidate effectiveness of teaching and learning of English language or any language. Students with grammar instruction can achieve accuracy in English language. Students who learn English on the go, after a moment, reach the language plateau beyond which they cannot progress. Their linguistic competence fossilizes. Research in Zhang (2009) suggests that learners who receive no instruction seem to be at risk of fossilizing sooner than those who do receive instruction. It is also true that learning grammatical distinctions requires a great deal of time even for the most skilled learners, but another important question is that it is possible to accelerate students natural learning of grammar through instruction. As of the recent popular Communicative Approach, it has false ideas that thinking the grammar is acquired virtually unconsciously and studying the rules of grammar is simply a waste of valuable time. But research finds that subjects who received grammar instruction progressed to the next stage after a two-week period, a passage normally taking several months in untutored development. Though the number of subjects studied was small, the finding provides evidence of the efficacy of grammar teaching over leaving acquisition to run its natural course.

Grammar instruction can help learners acquire grammar they would not have learned on their own. Some research points to the value of grammar instruction to improve learners' accuracy.

Grammar is a description of the regularities in a language, and knowledge of these regularities provides the learner with the means to generate a potentially enormous number of original sentences. The number of possible new sentences is constrained only by the vocabulary at the learner's command and his or her creativity. Grammar is a kind of 'sentence-making machine. It follows that the teaching of grammar offers the learner the means for potentially limitless linguistic creativity.

The linguist Stephen Krashen, in Zhang (2009) makes the distinction between learning and acquisition. Learning, according to Krashen, results from formal instruction, typically in grammar, and is of limited use for real communication. 
Acquisition is a natural process. It is the process by which the first language is picked up, and by which other languages are picked up solely through contact with speakers of those languages. Success in a second language is due to acquisition, not learning, moreover, he claims that learned knowledge can never become acquired knowledge. However, the researcher Richard Schmidt, in Zhang (2009), kept a diary of his experience learning Portuguese in Brazil. Initially he had enrolled in formal language classes where there was a heavy emphasis on grammar. When he left these classes to travel in Brazil, his Portuguese made good progress, a fact he attributed to the use he was making of it. As he interacted naturally with Brazilians, he was aware that certain features of the talk, certain grammatical items, seemed to catch his attention. He noticed them. It so happened that these items were also items he had studied in his classes. What's more, being more noticeable, these items seemed to stick. Schmidt concluded that noticing these facts was a prerequisite for acquisition.

The grammar teaching, he had received previously while insufficient in itself to turn him into a fluent Portuguese speaker, had primed him to notice what might have gone unnoticed. It had indirectly influenced his learning and had acted as a kind of advanced organizer for his later acquisition of the language. This observation can also be valuable for the acquisition of any other language.

Grammar is a system of learnable rules. It lends itself to a view of teaching and learning known as transmission. A transmission view sees the role of education as the transfer of a body of knowledge from those that have the knowledge to those that do not. Such understanding is typically associated with the kind of institutionalized learning where rules, order, and discipline are highly valued. Many learners come to language classes with somewhat fixed expectations to what they will do there. These expectations may derive from previous classroom experiences of language learning. They may also derive from experiences of classroom in general where teaching is of the transmission mode. On the other hand, their expectations that teaching will be grammar-focused may stem from frustration experienced at trying to pick up a second language in a non-classroom setting such as through self-study, or through immersion in the target language culture. Such students may have enrolled in language classes specifically to ensure that the learning experience is made more efficient and systematic.

The value of grammar teaching is important in English language and any other language teaching field. Grammar is the cement of English language or any other language. It is not acquired naturally, but learning, it needs to be instructed. Grammar operates at the sentence level and governs the syntax or word orders that are permissible in the language. It also works at the subsentence level to govern number and person agreement between subject and verb in a sentence. In learning grammar, some students may have a more analytical learning style than others. But if one hope to use English language or any language accurately and fluently, it is necessary to receive grammar rules instruction. Grammar is not different from anything else; it is likely that students will learn at different 
rates. Grammar teaching is necessary in English language or any other language teaching (Zhang, 2009).

\subsection{Five Facets of Effective English Language Teaching}

In an effective English language teaching (ELT) classroom, students learn and demonstrate understanding of meanings rather than merely memorizing facts or events. Teachers capitalize on reading because it affects success in other content areas and improve overall achievement gains. Students have higher achievement rates when the focus of instruction is on meaningful conceptualization, especially when it is built on and emphasizes their own knowledge of the world (Ghimire, 2019).

Uygun (2013) affirmed that an effective English language teacher is the one who is clear and enthusiastic in providing learners with the grammatical (syntactical and morphological), lexical, phonological, pragmatic, and socio-cultural knowledge. They provide interactive practices students need to communicate successfully in the target language. Students cannot learn efficiently if teachers do not teach effectively. To teach successfully, teachers need to be aware of different facets for effective ELT (Ghimire, 2019).

These five themes are: 1) effective and dynamic teachings, 2) active and creative learnings, 3) effective use of teaching and learning materials, 4) appropriate use of modern information technology, and 5) multiliteracy pedagogy in the classroom. These five themes are the major areas that need to be considered for effective ELT in the classroom. They help to develop competence as well as improve performance in student learning English (Ghimire, 2019).

In recent years, educators, researchers, policymakers, and other educational stakeholders have been engaged in an ongoing dialogue about the need for students to develop a broad repertoire of literacy practices. These practices are not confined to traditional views of literacy and traditional approaches of literacy instruction (Rajendram, 2015). The focus on language education in the $21^{\text {st }}$ century is no longer on grammar, memorization, and learning from rote, but rather using language and cultural knowledge as means to communicate and to connect to others around the globe (Eaton, 2010). The New London Group (1996) has proposed the concept of multiliteracy, which views literacy as continual, supplemental, and enhancing or modifying established literacy teaching and learning rather than replacing traditional practices (Rowsell, Kosnik, \& Beck, 2008 as cited in Benjamin, 2014). The integration of teaching multiliteracy has a potential to adopt new ideas and overcome the limitations of traditional learning approaches in the $21^{\text {st }}$ century literacies.

\subsection{Content and Language Integrated Learning (CLIL)}

According to Research Report \# 13-Effective Language Teaching: A Synthesis of Research, conducted by John Harris and Padraig O Duibhir (Duibhir \& Harris, 2011) on February 2011 in Dublin, research conducted on behalf of the Na- 
tional Council for Curriculum and Assessment, evidence shows that language learning is more effective when it is combined with content learning in another subject other than the language being learned. Content and Language Integrated Learning (CLIL) has been shown to improve students' language proficiency, without negatively impacting on the development of either the students' first language, or their performance in the subject area being taught. CLIL enables learners to encounter language in context and use it for authentic communication and challenges them to use the target language for cognitive purposes to acquire knowledge, skills and information.

\subsection{Intensive Language Programs}

According to the Report mentioned above, there is strong evidence to suggest that intensive programs of instruction in a second or additional language over a short time are more effective than intermittent programs where learners are exposed to limited amounts of the language over a longer period.

The reason intensive programs are more effective is that they allow opportunities for students to undertake sustained activities, use the language they have learned, and achieve a basic level of communicative ability that supports spontaneous communication and enhances motivation and success. The key difference between intensive language programs and Content Language Integrated Learning approaches is that the focus is on language learning (learning the language through communicative activities) rather than on content learning (learning the language of the subject). The traditional language teaching strategies focus on teaching the language such as English language and not on teaching the language of the subject also called the content language.

\subsection{Orientation of Language Programs (Communicative or Grammatical/Analytical Approaches) and the Importance of Teacher Factors}

The Report cited above notes that the evidence from research shows contradictory results: in some studies, communicative oriented courses did not result in any improvement in students' proficiency while in others, the language proficiency of learners in classrooms where experiential and communicative activities were emphasized, were better than those where there was a traditional grammatical/analytical approach. The conclusion is that the link between course design and student proficiency is quite weak and depends on context. It is not possible to design an ideal curriculum or course for every situation, and the critical concern should be achieving the right balance between communicative and analytical activities. Communicative approach leads to students learning social English and, grammatical and analytical approaches leads to students acquiring the mastery of the language also called academic English.

There is strong evidence to suggest that teacher's characteristics such as experience and skill are critical in achieving that balance. Teacher's competence is 
more important than the orientation of the language curriculum or course in supporting children's language development. Research has not so far provided clear guidance on what balance should be struck between form-focused and meaning or communication-focused activities.

\subsection{Development of L2 Literacy Skills}

According to the report, evidence shows that the development of students' L2 literacy skills supports the development of their second language proficiency in general. Reading aloud (teacher reading aloud to children) is a useful strategy to model correct pronunciation, stress and intonation and to help the children develop comprehension skills by focusing on units of meaning, especially in the beginning stages of language learning. Research findings recommend introducing L2 learners to literacy in a gradual way from the early stages of language learning, considering the wider literacy instruction in other languages in the school and L1 literacy. L2 reading strategies need to be explicitly taught.

Many writers suggest that developing L2 literacy skills can help to increase proficiency in the L2 and lead to increased motivation. One of the keys to improving L2 literacy skills is to provide students opportunities to read extended texts and to teach reading strategies to students.

\subsection{Process Type Research: Additional General Principles for Effective Language Teaching}

An overview of principles for effective language teaching was included in the process-type to provide a more complete picture of effective practice in language teaching. The main themes identified are:

- early language learning

- task-based interaction

- balancing form-focused and meaning activities

- listening comprehension and story-telling activities

- target language use

- the European Language Portfolio (ELP)

- language learning strategies

An early start in language learning can be beneficial to learners but does not guarantee success. It is a particular feature of the Primary School Curriculum that children in primary schools in Ireland benefit from the opportunity to begin learning two languages from the early years. To be successful, early language learning must be accompanied by effective teaching._It is also important to focus on meta-language, accuracy, and form, and to strike a balance between spontaneous communication and opportunities to plan and prepare productive language.

Task-based interaction has been shown to facilitate second language learning. In task-based interactions, the teacher creates activities or tasks which are more than language practice activities or drills, but where learners communicate ideas and feelings and receive feedback as to whether they have been unders- 
tood. These activities help learners develop production and comprehension skills and improve motivation. The role of teacher feedback and intervention needs to be carefully handled in these situations.

Balancing form-focused and meaning-focused activities is also important. Research has not yet provided clear guidance on the optimum balance, but some studies suggest that alternating between activities that focus on developing fluent expression and confidence and those that focus on accuracy of form and meaning can be useful.

Listening to and comprehending spoken natural language supports the development of comprehension. Through carefully planned listening activities, teachers can support learners develop comprehension strategies, including word and sound recognition and use context and previous knowledge to understand content in the target language. Story telling activities can also help to promote speaking proficiency and literacy skills.

Developing learning strategies can have positive effects on language learning over time, and even young children can become aware of and taught to use language learning strategies.

\subsection{Content and Language Integrated Learning}

Content and language integrated learning (CLIL) has been defined as a dual-focused educational approach in which an additional language is used for the learning and teaching of both content and language (Coyle, Hood, \& Marsh, 2010). CLIL is also described as "content-based instruction" in the North American context (Brinton, Snow, \& Wesche, 2003).

\section{Methodology}

\subsection{Introduction}

The purpose of this research was to find out how to improve teaching and learning in students with deficient language mastery. Three domains were examined: what we can do to provide teachers with the necessary knowledge to handle language teaching, instructional strategies needed to teach language mastery to students with language deficiencies, and whether students could be those suggesting better ways to teach language mastery.

\subsection{Research Design}

This study employed quantitative research to analyze the data collected from two questionnaire instrument designed specifically for the purpose of this study (Appendices A and B). The researcher selected to use directly administered questionnaire for its high response rate which typically reaches 100 percent. The other advantages of this method are the low cost and the fact that the researcher is present to provide assistance or answer questions of the respondents. This type of survey is administered to a group of participants assembled at a designated place for a specific purpose (Ary, Jacobs, \& Razavieh, 1996). 
Quantitative analysis is used to describe and forecast, to corroborate and confirm, and to experiment with hypotheses. It offers familiar variables, accepted guidelines and unchanged format, and is generally objective and independent of the environment. It usually involves a large sample using a standardized data collection methods and deductive analysis. The findings were addressed with objectivity, using numbers, statistics, and summative data (Gall, Borg, \& Gall, 1996; Leedy \& Ormrod, 2001).

\subsection{Sample}

The target population was identified as secondary school teachers and students in three high schools in the City of Kinshasa, the Capital of the Democratic Republic of the Congo. The accessible population was chosen based on the non-probability sampling technique known as convenience sampling. For each school surveyed, four high school classes were selected. English teachers and teachers of other languages were asked to take the survey voluntarily. Ten students per class were randomly and voluntarily asked to take the survey. Three more students volunteered to take the survey. The survey took place in the morning between 8:30 to 9:45 in school auditoriums. In each school, some teachers helped to administer the survey under the supervision of the researcher. It took the researcher three mornings to collect data. One hundred twenty-three $(\mathrm{N}=123)$ students and forty-four teachers $(\mathrm{N}=44)$ agreed to participate voluntarily. The researcher chose to utilize the data from all one hundred sixty-four $(\mathrm{N}=167)$ volunteers.

The researcher used the convenience sampling technique to bypass the lack of accessibility to some of these schools. Three high schools allowed the researcher access to teachers and students with limited time.

\subsection{Instrumentation}

The method of gathering data in this study was the questionnaire (Appendices A and B), which was content validated prior to use (Gall, Borg, \& Gall, 1996). The questionnaire was designed such that teachers and students would be able to understand it and answer appropriately. Also, the questionnaire was constructed to encompass findings of research related to this study preoccupation. Two sets of surveys were presented to respondents. One set for teachers concerning language teaching and the second set for students concerning language learning and acquisition. The questionnaire was pilot tested by five (5) teachers and ten (10) students not participating in the study. This was to ensure that the survey attained a level of comprehension and readability appropriate to respondents.

To collect data useful for evaluation of the research questions, the questionnaire used five-point numerical Likert-type scale to measure respondents' perceptions toward teachers' teaching strategies and students learning languages at the mastery level. The results of the Likert-type rating (i.e., 1 to 5) revealed the relative significance of every component of every research question. 


\subsection{Data Collection}

The researcher established contact with school principals to explain the purpose of the research study and to gain permission to conduct the study in their schools. The study was conducted in the City of Kinshasa, the Capital of the Democratic Republic of the Congo. The sample $(\mathrm{N}=167)$ was obtained by voluntary participation. The questionnaire was distributed to students and teachers in four high school auditoriums of each participating schools. The questionnaire was totally anonymous, and no identifying data were to be collected. For each school, the questionnaire was administered in 75 minutes and supervised by teachers and the researcher. Data were obtained from teachers and students. The answers to the questionnaire yielded information on all research questions.

\section{6, Data Analysis}

The purpose of this research was to find out how to improve teaching and learning in students with deficient language mastery. To answer the research questions, a questionnaire was administered to teachers and students (Appendices A and B). Data was collected from the total sample, consisting of teachers and students. Descriptive statistics (i.e., means and standard deviations) were calculated for the survey items.

Data collected to answer research question one (what can we do to make teaching language mastery as effective as necessary?) was grouped. Means and standard deviations were used to analyze the data. Item means were organized in rank-order.

Data collected to answer research question two (how can we determine whether students lack of language mastery is imputable to ineffective teaching in classroom?) was grouped. Means and standard deviations were used to analyze the data. Item means were organized in rank-order.

Data collected to answer research question three (what teaching strategies can help educators to provide students with language mastery?) was grouped. Means and standard deviations were used to analyze the data. Item means were organized in rank-order.

The means were rank ordered to determine how frequently teachers use effective teaching strategies aimed at students' language mastery. These data are necessary for the researcher because they expose the perceptions of teachers and students on teaching and learning the mastery of English language or any other languages. Statistical analyses were completed using the contemporary technology such as easycalculation.com to process the data.

\subsection{Limitations}

There were some limitations to the current research study, primarily concerning internal validity. The researcher surveyed only 123 students present in schools and 44 volunteer teachers. The research encompassed only three high schools in the City of Kinshasa, the capital of the Democratic Republic of the Congo. It 
could only be assumed that students and teachers understood all questions very well.

Although the study addressed student perceptions on language mastery and teachers' effectiveness in teaching languages, it did not examine teacher's training nor interview teachers. The researcher believed that students are the ones who produce results. Their opinions on teaching strategies could enlighten the research and help teachers to become more effective educators. The researcher felt that interviewing students and teachers on the same issue and at the same time would have produced biased results. Therefore, this aspect of research was reserved for future study.

\section{Analysis, Findings and Results}

\subsection{Introduction}

The purpose of this study was to find out how to improve teaching and learning in students with deficient language mastery. This chapter presents an analysis of the data collected from the questionnaire administered to 123 high school students aged spanning from 15 to 18 years old and 44 volunteer teachers in three high schools. The data was gathered to answer the following research questions:

1) What can we do to make teaching language mastery as effective as necessary?

2) How can we determine whether students lack of language mastery is imputable to ineffective teaching in classroom?

3) What teaching strategies can help educators to provide students with language mastery?

Descriptive statistics (means and standard deviation) were used to analyze the data generated through the administration of the questionnaire. Means and standard deviations yielded discrete data.

\subsection{Analysis}

The researcher grouped the results in two categories: the results from students and the results from teachers. Use of the statistical software, easycalculation.com, produced the data upon which the following analyses were based. Data requested to address research questions were organized using descriptive statistics (means and standard deviations). Surveyed students and teachers indicated their responses to research questions using a five-point numerical Likert-type scale.

\subsubsection{Research Question One:}

What can we do to make teaching language mastery as effective as necessary?

According to the data collected from surveyed teachers and students, our critical observations come from three essential questions: 
1) While teachers rank seven out of nine the question number nine (approaches to teaching grammar/grammatical analysis lead to a consistent mastery of the language) with $\underline{\mathrm{M}}=3.81$ and $\mathrm{SD}=1.26$, students rank it third $\underline{\mathrm{M}}=4.32$ and $\mathrm{SD}=0.96$. Students results shows more consistency in their responses than teachers'.

2) While teachers rank eight out of nine the question number seven (approaches to teaching grammar and grammatical analysis allow students to master the language more quickly) with $\underline{\mathrm{M}}=3.73$ and $\mathrm{SD}=1.17$, students rank it fifth with $\underline{\mathrm{M}}$ $=4.23$ and $\mathrm{SD}=1.09$. Teachers' response to this question shows less interest in using this teaching approach. Students appreciate this approach better than teachers.

3) While teachers rank fourth out of nine the question number one (my teacher constantly cultivates school relationships with me) with $\underline{\mathrm{M}}=3.95$ and SD $=1.35$. students rank it seventh with $\underline{M}=3.93$ and $\mathrm{SD}=1,16$.

The other questions surveyed did not present noticeable observations.

\section{Research Question Two:}

How can we determine whether students lack of language mastery is imputable to ineffective teaching in classroom?

According to the data collected from teachers and students, our critical observation come from one essential question. The question number two (my teacher insists on productive language in his classroom teachings). Teachers rank this question as number one with $\mathrm{M}=3.70$ and $\mathrm{SD}=1.11$ while students rank it number three out of four with $\mathrm{M}=3.86$ and $\mathrm{SD}=1.25$. Teachers and students rank last the question number four (my teacher regularly teaches analytical grammar in class), curiously.

\section{Research Question Three:}

What teaching strategies can help educators to provide students with language mastery?

According to the data collected from teachers and students, our critical observation come from two questions. For the question number one (my Teacher differentiates and uses several modalities, during teaching, to be understood by all students), teachers rank this question number three out of four while students rank it number one. Also, the question number four (My teacher always strives to integrate the teaching of the course content and that of the language), students rank this question number three while teachers rank if number one.

\subsection{Findings and Results}

\subsubsection{Research Question \# 1}

What can we do to make teaching language mastery as effective as necessary?

1) Students finding that the approaches to teaching grammar/grammatical analysis (\#9) lead to consistent mastery of the language, ranking it third, is more important while teachers find this strategy less important, ranking it seventh, indicate that teachers neglect the strategy that is capital in students' mastery of the 
language.

2) Students finding that the approaches to teaching grammar and grammatical analyses (\#7) allow them to master the language more quickly, ranking it fifth, while teachers rank it eighth indicates that these approaches are very important in students' language learnings but teachers found it not necessary.

3) Students found that the question about teachers-students relationship in school (\#1) is not what they observe in classrooms. They ranked it seventh. However, teachers indicate that they do apply this strategy by ranking it fourth. This shows a little controversy between students and teachers' opinions. This controversy can suggest that teachers do not mingle well with students to help facilitate their belonging in school.

\subsubsection{Research Question \# 2}

How can we determine whether students lack of language mastery is imputable to ineffective teaching in classroom?

Students' findings indicate that teaching and learning of productive language (\#2) is not remarkable in classrooms. They ranked it third out of four while teachers ranked it first. Also, the data collected shows that teachers and students mention that analytical grammar (\#4) is not regularly taught in classrooms. Both groups ranked this practice the last of the group. This agreement indicates that analytical grammar is almost not taught or not effectively in classrooms.

\subsubsection{Research Question \# 3}

What teaching strategies can help educators to provide students with language mastery?

Students found that the question about teaching differentiation and multi-modality strategies $(\# 1)$ is extremely important in their learning $(\underline{M}=4.30$ and $\mathrm{SD}=0.88)$. This SD shows how students are consistent in their response. Teachers, however, found this essential question less important ranking it number three out of four. This indicates that teachers are not really focusing on teaching students' language mastery.

For the question number 4 about integrating content and language teaching, students ranking it third out of four while teachers ranked it number one. This teachers' ranking - teaching the language of the content-indicates a missing use of important strategy on students' language mastery. Teachers claim they do use this practice while students' response shows an objection with $\underline{\mathrm{M}}=4.2$ and $\mathrm{SD}=$ 0.82 , a very consistent response. Students somewhat disagree with teachers' response as it shows on the data $\underline{M}=4.01$ and $\mathrm{SD}=1.18$ despite not being very consistent.

\subsection{Summary}

The data generated from this study present students' perceptions on strategies teachers use and strategies that they indicate help them to master the language at the academic level. Significant differences were observed for questions numbers 
one, six, seven and nine for research question one; question number two, three, four, five and eight did not present noticeable differences.

For research question number two, only question number two presented a considerable difference. Question number four did not present any difference at all while question numbers one and three presented minimal differences.

For research question three, questions number one and four presented noticeable differences. Question number two and three did not present any discrepancies. The questionnaire produced data that addressed the research questions and revealed the importance of teaching grammar and analytical grammar to students. The data indicated that teachers were not employing the strategies that research indicates as necessary for mastering a language. This data allowed the researcher to examine the questionnaire content and results and reflect upon the value of each of the language domain studied.

In this chapter, data collected from the questionnaire was presented in tables depicting the descriptive statistical analyses. The following chapter will present a summary of the major findings of this research with discussions, conclusions, implications, and recommendations.

\section{Discussions, Conclusions, Summary, and Recommendations}

\subsection{Introduction}

Students academic achievement is one of the major issues facing most students in developing countries. The case in the Democratic Republic of the Congo cannot be unique and deserve serious attention. This chapter is the culmination of the process used to examine and determine strategies teachers employ to teach language mastery in classrooms as well as students' preferences in learning the language at the academic level of language mastery. This chapter summarizes the results and discusses their implications.

\subsection{Discussions}

The results of this study highlight several important findings that are critical to ensuring effective teaching of language to all students in classrooms. The data produced by this study (Table 1 for teachers and Table 2 for students) show that students prefer the item number 8 (approaches to teaching social communication or dialogue lead to a coherent mastery of the language), ranking it first with $\underline{\mathrm{M}}=$ 4.46 and $\mathrm{SD}=0.96$ while for the same item teachers rank it third with $\underline{\mathrm{M}}=3.73$ and $\mathrm{SD}=1.17$; students prefer the item number 7 (approaches to teaching grammar/grammatical analysis lead to a consistent mastery of the language), ranking it third with $\underline{\mathrm{M}}=4.32$ and $\mathrm{SD}=0.96$ while teachers, for the same item, rank it seven with $\underline{\mathrm{M}}=3.81$ and $\mathrm{SD}=1.26$; Students rank seventh the item number one (my teacher constantly cultivates school relationships with me), with $\underline{\mathrm{M}}=3.93$ and $\mathrm{SD}=1.16$ while teachers rank the same item fourth with $\underline{\mathrm{M}}=$ 3.95 and $\mathrm{SD}=1.35$. The results might suggest that teachers do not focus on teaching grammar and analytical grammar to reinforce language mastery. 
Table 1. Survey results as reported by teachers presented in rank-ordered means.

\section{Items}

1) (4) Teaching grammar is a necessity to improve the mastery of the language

2) (6) Approaches to teaching language for communication allow students to master the language more quickly

3) (8) Approaches to teaching social communication or dialogue lead to a coherent mastery of the language by students

4) (1) I constantly cultivate academic relationships with my students

5) (5) Intensive language programs rapidly improve students' language skills

6) (2) I take into account the culture of my students in my teachings when I use the official language of communication in class

7) (9) Approaches to teaching grammar/grammatical analysis lead to consistent mastery of the language by students

8) (7) Approaches to teaching grammar and grammar analysis allow students to master the language faster

9) (3) I often use technology in my teachings

(Data collected from teachers' survey on effective language mastery).

Table 2. Survey results as reported by students presented in rank-ordered means.

\begin{tabular}{|c|c|c|}
\hline Items & $\begin{array}{l}\text { Means } \\
\underline{M}\end{array}$ & $\begin{array}{c}\text { Standard } \\
\text { Deviations } \\
\text { SD }\end{array}$ \\
\hline 1) (8) Approaches to teaching social communication or dialogue lead to a coherent mastery of the language & 4.46 & 0.96 \\
\hline 2) (4) Teaching grammar is a necessity to improve language proficiency & 4.33 & 1.14 \\
\hline 3) (9) Approaches to teaching grammar/grammatical analysis lead to a consistent mastery of the language & 4.32 & 0.96 \\
\hline 4) (5) Intensive language programs quickly improve my language skills & 4.30 & 1.04 \\
\hline $\begin{array}{l}\text { 5) (7) The approaches to teaching grammar and grammatical analysis allow me to master the language very } \\
\text { quickly }\end{array}$ & 4.23 & 1.09 \\
\hline $\begin{array}{l}\text { 6) (2) My teacher takes my culture into account in his teaching when using the official language of } \\
\text { communication in the classroom }\end{array}$ & 4.21 & 1.13 \\
\hline 7) (1) My teacher constantly cultivates school relationships with me & 3.93 & 1.16 \\
\hline 8) (6) Approaches to teaching social communication or dialogue lead to a coherent mastery of the language & 3.76 & 1.21 \\
\hline 9) (3) My teacher often uses technology in his teachings. & 3.53 & 1.38 \\
\hline
\end{tabular}

(Data collected from students survey on effective language mastery).

Students state that item \# two (my teacher insists on productive language in his classroom teachings) is less important ranking it third out of four with $\underline{M}=$ 3.86 and $\mathrm{SD}=1.25$ (Table 3 ) while teachers rank the same item number one, meaning very important, with $\underline{M}=3.70$ and $\mathrm{SD}=1.11$ (Table 4); Teachers and students rank item four (my teacher regularly teaches analytical grammar in class), the last. Again, this is an indication that teachers do not focus on teaching 
Table 3. Survey results as reported by students presented in rank-ordered means.

\begin{tabular}{lcc}
\hline Items & Means & Standard Deviations \\
\hline 1) (3) My Teacher regularly teaches grammar in class & 4.00 & 1.14 \\
$\begin{array}{l}\text { 2) (1) My teacher teaches language skills throughout } \\
\text { the course program }\end{array}$ & 3.95 & 1.21 \\
$\begin{array}{l}\text { 3) (2) My teacher insists on productive language in his } \\
\text { classroom teachings }\end{array}$ & 3.86 & 1.25 \\
$\begin{array}{l}\text { 4) (4) My teacher regularly teaches analytical grammar } \\
\text { in class }\end{array}$ & 3.53 & 1.03 \\
\hline
\end{tabular}

(Data collected from students survey).

Table 4. Survey results as reported by teachers presented in rank-ordered means.

\begin{tabular}{lcc}
\hline \multicolumn{1}{c}{ Items } & Means & Standard Deviations \\
\hline $\begin{array}{l}\text { 1) (2) I insist on productive language in my classroom } \\
\text { teachings }\end{array}$ & 3.70 & 1.11 \\
2) (3) I regularly teach grammar in my class & 3.59 & 1.33 \\
$\begin{array}{l}\text { 3) (1) I teach language skills throughout the course } \\
\text { program }\end{array}$ & 3.43 & 1.35 \\
$\begin{array}{l}\text { 3) (4) I regularly teach analytical grammar in my class } \\
\text { (2) }\end{array}$ & 3.09 & 1.30
\end{tabular}

(Data collected from teachers' survey on students' language mastery).

Table 5. Survey results as reported by teachers presented in rank-ordered means.

\begin{tabular}{lcc}
\hline Items & Means & Standard Deviations \\
\hline 1) (4) I always strive to integrate the teaching of course & 4.20 & 0.82 \\
content and language into my students & & 1.28 \\
2) (3) I always aim to encourage the spirit of reading in & 3.93 & 1.22 \\
my class for each course & & \\
3) (1) I differentiate and use several modalities during & 3.59 & 1.19 \\
teaching to be understood by all my students & \\
4) (2) I often notice a lack of language skills in my & 3.14 \\
students at the beginning of the school year &
\end{tabular}

(Data collected from teachers' survey on language teaching strategies).

the language mastery effectively.

Even though teachers and students rank item two equally, meaning four out of four, (I often notice a lack of language skills in myself and my colleagues at the beginning of the school year) (Table 5 and Table 6) as least important in their language teaching and learning, this item cannot be neglected, because it is basic in teaching to take students where they are at the beginning of school year and to bring them up to where the teachers want them to be above the required standard. For the item four (my teacher always strives to integrate the teaching of the course content and that of the language), students rank it third with $\underline{M}=$ 
Table 6. Survey results as reported by students presented in rank-ordered means.

\begin{tabular}{lcc}
\hline Items & Means & Standard Deviation \\
\hline $\begin{array}{l}\text { 1) (1) My Teacher differentiates and uses several modalities } \\
\text { during teaching to be understood by all students }\end{array}$ & 4.30 & 0.88 \\
$\begin{array}{l}\text { 2) (3) My teacher always aims to encourage the spirit of } \\
\text { reading in class for each course }\end{array}$ & 4.05 & 1.25 \\
3) (4) My teacher always strives to integrate the teaching & 4.01 & 1.18 \\
of the course content and that of the language & \\
4) (2) I often notice a lack of language skills in myself & 3.60 & 1.19 \\
and my colleagues at the beginning of the school year & & \\
\hline
\end{tabular}

(Date collected from students' survey on language teaching strategies).

3.60 and $\mathrm{SD}=1.18$ while teachers rank this it first with $\underline{\mathrm{M}}=4.20$ and $\mathrm{SD}=0.82$. The mismatch between teachers preferred strategies and the practices identified by students as better suggests that teachers might benefit from recognition of these discrepancies.

\subsection{Conclusion}

Research in education continually discovers new information about teaching and learning. To meet the challenges of educating students in the $21^{\text {st }}$ century, educators must adjust teaching and learning to meet the learning needs of every student, in this case, the mastery of the language and an effective use of academic language. For teachers to be successful in providing effective language mastery, education leaders must establish a reliable accountability system as well as structured professional developments.

Teachers need to continually assess students' academic language acquisition and proficiency, considering any student with deficient academic language. They must also focus on providing students with an environment conducive to developing academic language. Mastery of academic language is key to success in academic world.

\subsection{Summary}

The purpose of this research study was to make teaching language mastery as effective as necessary, to determine whether students lack of language mastery is imputable to ineffective teaching in classrooms and what teaching strategies can help educators to provide students with the language mastery. The findings from surveyed students were analyzed to contextualize that is to determine whether their impressions of effective language teaching and learning depended on their actual achievement scores. The data show that there are considerable differences between the strategies teachers find important and the teaching strategies students consider most effective in their learning. Considering these data, the researcher has suggested that students' preferred teaching strategies be recommended to teachers within the context of professional development. Even though 
there are few significant differences between the overall strategies teachers find very important and those students consider most effective in their learning, consideration must be given to these differences so that teachers can emphasize the strategies considered most effective, as indicated by high means and low standard deviations.

\subsection{Proposed Actions as a Result of This Study/Recommendations}

Although the results of this study may not be generalizable to all schools, there are clear implications for all educators involved in improving the teaching and the learning of language mastery at the academic level. The followings are suggestions to reach language mastery objectives:

1) Intensify the teaching and the learning of grammar at every level of teaching for at least one hour a day.

2) Intensify analytical grammar in teaching and learning every day. This strategy is aimed at reinforcing the practical part of learning the language.

3) Intensify writing activities that require effective use of analytic grammar.

4) We recommend that the teaching of grammar and analytical grammar be taught with emphases at every level of elementary and secondary education depending on school curriculum coordination and articulation.

\section{Conflicts of Interest}

The author declares no conflicts of interest regarding the publication of this paper.

\section{References}

Ary, D., Jacobs, L. C., \& Razavieh. (1996). Introduction to Research in Education. Harcourt Brace \& Company.

Benjamin, B. (2014). Multiliteracies in the Classroom: Emerging Conceptions of First-Year Teachers. Journal of Language and Literary Education, 10, 114-135. https://files.eric.ed.gov/fulltext/EJ1030724.pdf

Brinton, D., Snow, M. A., \& Wesche, M. B. (2003). Content-Based Second Language Instruction (New ed.). University of Michigan Press.

Chong, L. K. (2016, June 12). Lack of Language Proficiency. The Star. https://www.thestar.com.my/news/education/2016/06/12/lack-of-language-proficiency

Coyle, D., Hood, P., \& Marsh, D. (2010). CLIL: Content and Language Integrated Learning. Cambridge University Press.

Duibhir, P. O., \& Harris, J. (2011). Effective Language Teaching: A Synthesis of Research. National Council for Curriculum and Assessment.

Eaton, S. E. (2010). Global Trends in Language Learning in the Twenty-First Century. Onate Press.

Foppoli, J. (2014). Is Grammar Really Important for a Second Language Learner? Eslbase. https://www.eslbase.com/teaching/grammar-important-second-language-learner

Gall, M. D., Borg, W. R., \& Gall, J. P. (1996). Education Research: An Introduction (6th ed.). Longman Publication. 
Ghimire, N. B. (2019). Five Facets for Effective English Language Teaching. Journal of NELTA Gandaki, 2, 65-73.

Kaplan, E. (2019, April 12). 6 Essential Strategies for Teaching English Language learners. Edutopia.

https://www.edutopia.org/article/6-essential-strategies-teaching-english-language-learn $\underline{\text { ers }}$

Language Center (2017, September 15). The 5 Pillars of Effective Language Teaching. University of Groningen.

https://www.rug.nl/language-centre/about-us/mission-vision/pillars-of-teaching?lang= en

Leedy, P. D., \& Ormrod, J. E. (2001). Practical Research: Planning and Design. Merrill, Practice Hall.

New London Group (1996). A Pedagogy of Multiliteracies: Designing Social Futures. Harvard Educational Review, 66, 60-92.

Rajendram, S. (2015). Potentials of the Multiliteracies Pedagogy for Teaching English Language Learners (ELLs): A Review of the Literature. Critical Intersections in Education: An OISE/UT Students' Journal, 3, 1-18.

USAID (United States Agency for International Development) (2020, May 27). Improving Systems for Reading Instruction: Global Reading Network.

https://www.globalreadingnetwork.net/learning/improving-reading-instruction

Uygun, S. (2013). How to Become an Effective English Language Teacher. Journal of Educational and Social Research, 3, 306-311.

Zhang, J. (2009). Necessity of Grammar Teaching. International Education Studies, 2, 184-187. 


\section{Appendices}

\section{Appendix A: Survey Questionnaire for Teachers}

Instructions: For each item, circle the number that closely expresses what you do.

I. Please, indicate your agreement with the following teaching practices or considerations. (From $1=$ least agreement to $\mathbf{5}=$ most agreement):

1. I constantly cultivate school relationships with my students.
1
2
3
4
5

2. I am culturally responsive in my teaching in language classroom.
1
2
3
4
5

3. I often use technology in my teaching.

1

2

3

4

5

4. Grammar teaching is a necessity in improving language mastery.
2
3
4
5

5. Intensive language programs improve student language proficiency faster and better.

1

2

3

4

5

6. Communicative teaching approaches lead to student language proficiency faster.

1

2

3

4

5

7. Grammatical/analytical teaching approaches lead to student language proficiency faster.

1

2

3

4

5

8. Communicative teaching approaches lead to student consistent language mastery.
1
2
3
4
5

9. Grammatical/analytical approaches lead to student consistent language mastery.

$\begin{array}{lllll}1 & 2 & 3 & 4 & 5\end{array}$

2. Please, rate the frequency of the following teaching practices you use in your classroom. (From $1=$ least used to $\mathbf{5}=$ most used):

1. I teach language skills across the curriculum.
1
2
3
4
5

2. I emphasize productive language in my teaching in classroom.

$\begin{array}{lllll}1 & 2 & 3 & 4 & 5\end{array}$

3. I regularly teach grammar notions in my classroom.

1

2

3

4 
4. I regularly teach analytical grammar in my classroom.

1

2

3

4

5

3. Please, rate the frequency of the following teaching strategies you use in your classroom. (From $1=$ least used to 5 most used):

1. I differentiate and use multiple modalities when teaching my students.

2. I often notice lack of language proficiency in my students at the start of course.

3. I always aim at improving reading instructions in my classroom.

4. I always focus on integrating teaching content and language in my students.

\section{Appendix B: Survey Questionnaire for Students}

Instructions: For each item, circle the number that closely expresses what your teachers do in class.

I. Please indicate your agreement with the teaching practices or considerations observed during the teachings (what your teachers practice). (From $1=$ less agreement to $5=$ more agreement):

1. My teacher (teacher) constantly cultivates school relations with students
1
2
3
4
5

2. My teacher takes culture into account when he uses the official language of communication in class.

1

2

3

4

5

3. My teacher often uses technology in teaching.

1

2

3

4

5

4. Teaching grammar is a necessity to improve the mastery of the French or English language.

1

2

3

4

5

5. Intensive language programs rapidly improve language skills.
1
2
3
4
5

6. The approaches to teaching the language for communication allow me to master the language more quickly.

1

2

3

4

5

7. Grammar teaching approaches and grammatical analyses allow me to master the language more quickly.

1

2

3

4

5

8. Approaches to teaching social communication or dialogue lead to a coherent mastery of the language.

$\begin{array}{lllll}1 & 2 & 3 & 4 & 5\end{array}$

9. Approaches to teaching the notions of grammar/grammatical analyses lead to a coherent mastery of the language.

1

2

3

4

5 
2. Please note the frequency of the following teaching practices that your teachers use in your classroom. (From $\mathbf{1}=$ least used to $\mathbf{5}=$ most used):

1. My teacher teaches language skills throughout the course curriculum.

1

2

3

4

5

2. My teacher insists on productive language in classroom teaching.

2

3

4

5

3. My teacher regularly teaches the notions of grammar in class.
1
2
3
4
5

4. My teacher regularly teaches analytical grammar in class.

$\begin{array}{lllll}1 & 2 & 3 & 4 & 5\end{array}$

3. Please note the frequency of the following teaching strategies that teachers use in your classroom. (From $1=$ least used to $5=$ most used):

1. My teacher differentiates and uses several modalities during teaching to be understood by all students.

1

2

3

4

5

2. I often notice a lack of language skills in myself and my classmates at the beginning of the school year.

2

3

4

5

3. My teacher always aims to encourage the spirit of reading in class for every class.

1

2

3

4

5

4. My teacher always strives to integrate the teaching of the course content and that of the language.

2

3

4

5 